\title{
Evaluation of coenopopulations of some nemoral species in pine types of communities
}

\author{
Elena Dushina*, Maria Shakleina, and Ksenia Belova \\ Vyatka State University, 610000 Kirov, Russia
}

\begin{abstract}
The authors of the article have evaluated the state and structure of coenopopulations of nemoral species using the example of Convallaria majalis L. and Polygonatum odoratum (Mill.) Druce. Three cenopopulations of P. odoratum (CPP.1 - CPP.3) and four of C. majalis (CPC.4 - CPC.7) have been described while studying three quarters of the Medvedsky Bor nature sanctuary. The authors have come to the conclusion that all the studied coenopopulations of P. odoratum and C. majalis were normal juvenile incomplete. Due to the high demand of C. majalis and P. odoratum in soil moisture, their existence in the pine communities of the Medvedsky Bor nature sanctuary is ensured by the presence of green mosses that retain moisture on the substrate surface.
\end{abstract}

\section{Introduction}

Pine forests represent special communities: they do not form their own natural zone. They are formed on the territory of the northeastern European part of Russia by plants Pinus sylvestris $L$. from different migration waves. On the territory of the natural sanctuary "Medvedsky Bor" they are relict communities of the postglacial xerothermal epoch on the continental sand dunes. Due to the prevailing biotope conditions, pine forests often contain pine forests, boreal species, and plants from other ecological-coenotic groups, for example, nemoral ones. In particular, representatives of the latter include May lily of the valley (Convallaria majalis L.) and fragrant bush (Polygonatum odoratum (Mill.) Druce), which are the objects of our study. Previously, the features of biomorphology were studied and the parameters of the counting units of their coenopopulations were identified [1]. The aim of this research is to assess the state and structure of coenopopulations (CP) of C. majalis and $P$. odoratum in pine types of communities.

\section{Material and methods}

The research was carried out in May 2021 on the territory of 68, 75 and 117 quarters of the Medvedsky Bor nature sanctuary, the Nolinsky district of the Kirov region. In the course of this analysis, three CPs of P. odoratum (CP P.1, CP P.2, CP P.3) and four CPs of $C$. majalis (CPC.4, СРC.5, CPC.6, СРC.7) were analyzed. Descriptions of plant communities

*Corresponding author: lenochkadushina@mail.ru 
were carried out according to generally accepted geobotanical methods [2]. To study the age spectrum and the number of coenopopulations of vegetatively mobile species, partial formations were taken as counting units [3]. Therefore, we took into account individual partial shoots of $C$. majalis and P. odoratum (individuals). Their assignment to specific ontogenetic states was carried out according to the data of a number of studies [4-9]. During office processing, the age spectra of CP were calculated based on the ratio of different age groups, which were expressed as a percentage of the total number of individuals and their types were estimated [10]. The indices of age and energy efficiency [11], recovery $\left(\mathrm{J}_{\mathrm{B}}\right)$ and replacement $\left(\mathrm{J}_{3}\right)$ [12] were used as integral characteristics of the ontogenetic structure of coenopopulations of species. The type of $\mathrm{CP}$ of the studied species was determined according to the classification $(\Delta-\omega)[11]$.

\section{Results and their discussion}

Coenopopulations 1 and 4 (CPP.1 and CPC.4) are located in block 68, section 10, in a cowberry-green moss pine forest with a stand composition of $10 \mathrm{C}$ and a crown closure of 0.2 on the northern slope with a steepness of $10-15^{\circ}$. The undergrowth is represented by Pinus sylvestris L., Picea abies (L.) H. Karst., Betula pendula Roth and Quercus robur L. The projective cover of the grass-dwarf shrub layer is $80 \%$, it is composed of the following species: Vaccinium vitis-idaea L., Calamagrostis arundinacea (L.) Roth, C. majalis, P. odoratum, Melampyrum sylvaticum L., Luzula pilosa (L.) Willd., Orthilia secunda (L.) House, Pulsatilla patens (L.) Mill., Vaccinium myrtillus L., Dryopteris carthusiana (Vill.) H. P. Fuchs, Trommsdorffia maculata (L.) Bernh., Trientalis europaea L. and Solidago virgaurea L. The moss-lichen cover evenly covers the entire area of coenopopulations (100\%) and is represented by Pleurozium schreberi (Brid.) Mitt., Dicranum scoparium Hedw., Dicranum polysetum Sw. and Cladonia arbuscular (Wallr.) Flot.

Coenopopulation 2 (CPP.2) was analyzed in quarter 75, section 18, in a green moss pine forest with a stand composition of $10 \mathrm{C}$ and a crown closure of 0.3 . The undergrowth has only B. pendula. The herb and shrub layer with a projective cover of $20 \%$ is represented by $V$. vitis-idaea, C. majalis, $P$. odoratum and $P$. patens. The projective cover of the mosslichen layer is $100 \%$, it includes $P$. schreberi, D. polysetum, $C$. arbuscula, Hylocomium splendens (Hedw.) Bruch et al., Cladonia rangiferina (L.) F. H. Wigg. and Cladonia alpina (Asahina) Yoshim.

Coenopopulations 3 and 7 (CPP.3 and CPC.7) are located in quarter 117, section 40, in a reed-cowberry-green moss pine forest (stand composition $6 \mathrm{C} 4 \mathrm{C}$, crown closure 0.2 ). The undergrowth includes $P$. sylvestris, $P$. abies, B. pendula, $Q$. robur and $P$. tremula. The total projective cover of the grass-dwarf shrub layer is $60 \%$, it includes V. vitis-idaea, C. arundinacea, Solidago virgaurea L., C. majalis, P. odoratum, O. secunda, P. patens, Dryopteris carthusiana (Vill.) H.P. Fuchs, Chamaenerion angustifolium (L.) Scop. and Chimaphila umbellata (L.) W.P.C. Barton. The moss-lichen cover is dominated by Pleurozium schreberi (Brid.) Mitt. with a projective cover of $80 \%$.

Coenopopulation 5 (CPC.5) was described in quarter 68, section 9 and confined to the forb-green moss pine forest. The composition of the stand was 10C, the crown closure - 0.3. The undergrowth had P. sylvestris, P. abies, B. pendula, Q. robur and Populus tremula L. The herb-dwarf shrub layer with a projective cover of $90 \%$ includes $V$. vitis-idaea, C. arundinacea, Pyrola rotundifolia L., Rubus saxatilis L., C. majalis, P. odoratum, L. pilosa, P. patens, Viola canina L., V. myrtillus, Chimaphila umbellata (L.) W.P.C. Barton, T. europaea, Linnaea borealis L. and Equisetum hyemale L. Moss and lichen cover (projective cover $-80 \%$ ) is represented by $P$. schreberi, D. scoparium, D. polysetum and C. arbuscula. 
Coenopopulation 6 (CPC.6) is located in a spruce-pine blueberry-lily of the valley forest with a stand composition of 6C4E and a crown closure of 0.4 . The undergrowth is represented by $P$. abies, B. pendula, $Q$. robur and $P$. tremula. The herb-dwarf shrub layer (projective cover is $90 \%$ ) is distinguished by a very high species diversity (26 species), dominated by: $R$. saxatilis, $C$. majalis and V. myrtillus. The projective cover of the mosslichen layer is $30 \%$, this layer is represented by $P$. schreberi, D. polysetum and Climacium dendroides (Hedw.) F. Weber \& D. Mohr.

The state of $P$. odoratum coenopopulations is the following. Among the ontogenetic states of individuals in CPP.1, generative individuals predominate. The indices of replacement and recovery are equal due to the absence of representatives of the senile ontogenetic state (as in CPP.2 and CPP.3) and amount to 1.05. Based on the values of the age index (0.16) and energy efficiency (0.49), the coenopopulation is young according to the delta-omega classification. Thus, CPP.1 can be characterized as normal juvenile incomplete.

In CPP.2, the recovery and replacement indices are 2.18. Indicators of the indices of age and energy efficiency ( 0.11 and 0.36 , respectively) make it possible to classify this $\mathrm{CP}$ as a young one. Among ontogenetic states, immature ones prevail. All of the above gives grounds to characterize CPP.2 as normal juvenile incomplete.

The recovery index in CPP.3 is also equal to the replacement index (3.29), and the indicators of age (0.09) and energy efficiency (0.31) indicate that the coenopopulation is young. The coenopopulation is dominated by immature individuals. It can be concluded that CPP.3 is normal juvenile incomplete.

The state of $C$. majalis coenopopulations is the following. In CPC.4, the indices of recovery and replacement are 0.65 and 0.63 , respectively. Based on the values of the indices of age (0.21) and energy efficiency (0.61), the coenopopulation is maturing with a predominance of generative individuals. Thus, CPC.4 is normal maturing incomplete.

Among the ontogenetic states of individuals in CPC.5, generative individuals predominate. The replacement and recovery indices are 0.8 and 0.94 , respectively. Based on the values of the indices of age (0.25) and energy efficiency $(0.58)$, the coenopopulation is young according to the delta-omega classification. Thus, CPC.5 is normal juvenile incomplete.

In CPC.6, values of the replacement and recovery indices are 2.56 and 4.6, respectively, and according to the age $(0.23)$ and energy efficiency $(0.44)$ indices, the coenopopulation belongs to the "young" type. The coenopopulation is dominated by virginal individuals. It can be concluded that CPC.6 is normal juvenile incomplete.

The replacement and recovery indices in CPC.7 are 1.37 and 1.48 , respectively. The indices of age and energy efficiency indices ( 0.20 and 0.54 , respectively) make it possible to classify this coenopopulation as a young one. Among ontogenetic states, virginal ones predominate. Thus, the CPC.7 of $C$. majalis can be characterized as normal juvenile incomplete.

Based on the ratio of individuals of different ontogenetic states in the studied coenopopulations, the authors compiled their ontogenetic spectra (Fig.). For CPP.1, the spectrum resembles a bimodal one with peaks in immature and generative individuals. The ontogenetic spectra of CPP.2 and CPP.3 are left-sided with a maximum on individuals of the immature state. In CPP.3, it is intermittent, since individuals of the virginal ontogenetic state are absent. Left-sided spectra with peaks on generative individuals can be observed in CPC.4 and CPC.5, and with maxima on virginal - CPC.6 and CPC.7. 


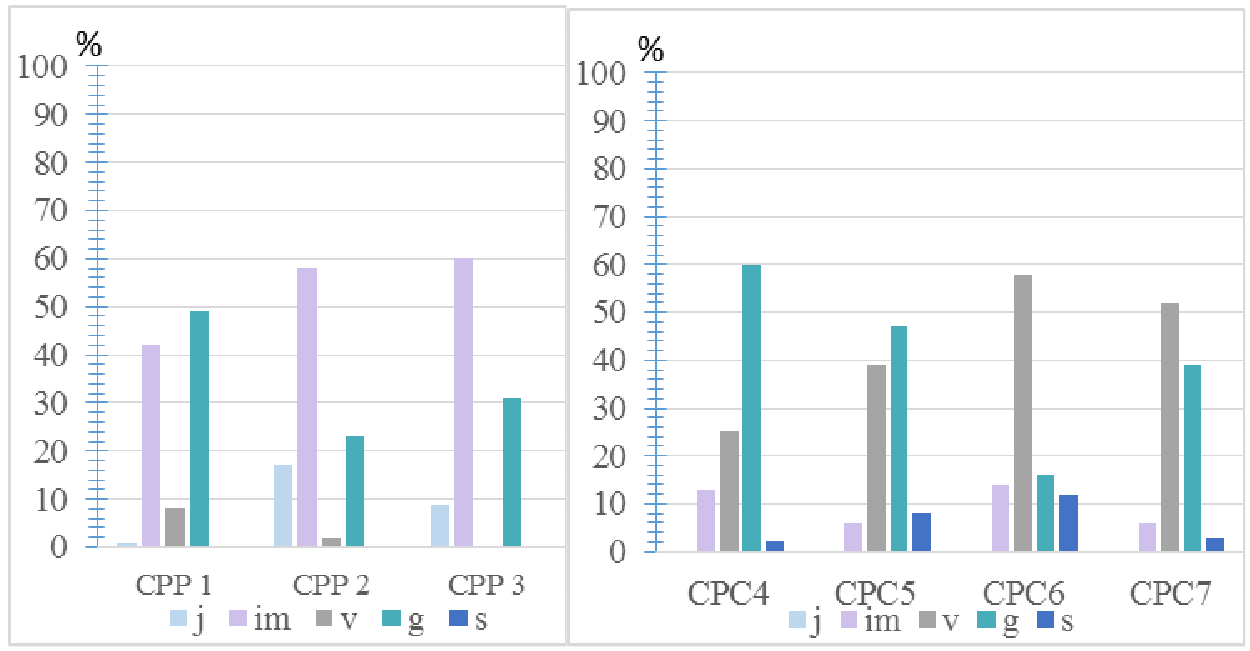

Fig. Ontogenetic spectra of the studied CP: CPP 1, 2, 3-P. odoraum, CPC 4, 5, 6, 7 - C. majalis

\section{Conclusion}

Thus, in the course of the study, the authors evaluated the coenopopulations of $C$. majalis and $P$. odoratum, confined to forest pine communities. For the coenopopulations of $P$. odoratum, the following was stated: individuals of the generative period predominate in CPP.1, while СРP.2 and СРP.3 have significantly more representatives of the pregenerative period. It indicates a fairly stable position of the species in these communities; indices of recovery and replacement indices indicate a fairly successful self-maintenance of all three coenopopulations. For the studied coenopopulations of $C$. majalis, it was noted that generative individuals predominate in CPC.4 and CPC.5, while virginal individuals prevail in CPC.6 and CPC.7. As a result of the rejuvenation of generative individuals of $C$. majalis, immature and virginal ontogenetic states were noted in the studied CPs. Due to the high demand of $C$. majalis and $P$. odoratum in soil moisture, their existence in pine communities of the Medvedsky Bor nature sanctuary is ensured by the presence of green mosses that retain moisture on the surface of the substrate.

\section{References}

1. E. E. Dushina, N. P. Savinykh, On counting units in the study of coenopopulations of Convallaria majalis L. in pine forests of the Medvedsky Bor. Materials of the XVIII All-Russian scientific-practical conference with international participation "Biodiagnostics of the state of natural and natural-technogenic systems", November 18, 2020 Kirov, Russia (2020)

2. V. S. Ipatov, M. D. Mirin, Description of phytocenosis: Methodical recommendations (St. Petersburg, 2008)

3. L. B. Zaugolnova, L. A. Zhukova, I. M. Ermakova, O. P. Vedernikova, N. M. Grigorieva, V. N. Egorova, A. R. Matveev, O. V. Smirnova, O. A. Sheypak, Study of the structure and relationship of coenopopulations. Methodological developments for students of biological specialties (Moscow State Pedagogical Institute named after V. I. Lenin, Moscow, 1986) 
4. I. L. Krylova, Biological flora of the Moscow region, 1 (Moscow, Publishing house of Moscow University, 1974)

5. U. Perttula, Untersuchungen uber die generative und vegetative Vermehrung der Blutenpflanzen (Helsinki, 1941)

6. E. V. Katsovets, Ecological and phytocenotic features of May lily of the valley in the steppe Trans-Volga region (on the example of the Krasnosamar forest massif) (Samara, 2011)

7. S. A. Balandin, T. P. Balandina, Biological flora of the Moscow region, 11 (Moscow, Argus, 1995)

8. I. I. Istomina, M. E. Pavlova, A. A. Terekhin, Bulletin of Peoples' Friendship University of Russia, Series Agronomy and Livestock, 1 (2016)

9. N. Riznichuk, Bulletin of Lviv University, Seriya biologichna, 59 (2012)

10. L. B. Zaugolnova, Coenopopulations of plants (basic concepts and structure) (Moscow, Nauka, 1976)

11. L. A. Zhivotovsky, Ecology, 1 (2001)

12. L. A. Zhukova, Population life of meadow plants (Yoshkar-Ola, 1995) 